\title{
CS-16 Prevalencia de enfermedad renal crónica de causa no tradicional (ERCnT) en pacientes en hemodiálisis de la costa sur de Guatemala
}

\author{
Prevalence of chronic kidney disease of non-traditional causes in patients on \\ hemodialysis in southwest Guatemala \\ Timothy S. Laux ${ }^{2}$, Joaquín Barnoya², Ever Cipriano ${ }^{1}$, Erick Herrera ${ }^{1}$, \\ Noemí López ${ }^{2}$, Marcos Rothstein², Vicente Sánchez-Polo ${ }^{1}$
}

${ }^{1}$ Servicio de Nefrología y Trasplante Renal, Hospital General de Enfermedades, Instituto Guatemalteco de Seguridad Social, Guatemala y ${ }^{2}$ Departamento de Nefrología, Universidad de Washington, St, Louis Mo, USA

*Autor al que se dirige la correspondencia: visanpolo@gmail.com

\section{Resumen}

T a enfermedad renal crónica (ERC) de causa no tradicional (ERCnT) se presenta frecuentemente en la costa sur de América Central y regiones de Sri Lanka. Poco se sabe de esta patología pero, afecta poblaciones jóvenes, trabajadores de la agroindustria que se exponen al golpe de calor, viven debajo de $200 \mathrm{~m} . \mathrm{snm}$, tienden a tener poca proteinuria y no se asocian a factores tradicionales de ERC, además se reconocen otros factores como, deshidratación frecuente, rabdomiolisis, uso de AINES, contexto de pobreza, bajo peso al nacer y malnutrición. Se estableció la prevalencia de pacientes con ERCnT y los factores asociados a través de un estudio descriptivo de corte transversal en donde se entrevistaron 242 pacientes que reciben tratamiento de hemodiálisis en diferentes unidades de la costa sur (Escuintla, Mazatenango y Retalhuleu). Los pacientes fueron clasificados en diabéticos, hipertensos, obesos o si ninguno de esos factores. Se analizó la relación entre pacientes con factores no tradicionales de ERC: ocupación, demográficos, hábitos, altitud y tiempo en llegar a su clínica de diálisis, usando un análisis multivariado de regresión logística. Se encontró que 171 (71\%) pacientes no presentaron factores tradicionales de ERC. Aunque la ocupación de agricultor es la más común, únicamente alcanzó significancia estadística la edad $<50$ años y el tiempo $>30$ min que tardan en desplazarse a la clínica de diálisis. El uso de AINES y consumo de bebidas carbonatadas fue descrito como frecuente. La prevalencia de ERCNT en pacientes que reciben hemodiálisis en la costa sur de Guatemala es alta. Es el mismo fenómeno reportado en El Salvador y Nicaragua. Queda entonces demostrado que la ERCnT también se presenta en la costa sur de Guatemala.

Palabras claves: América Central; insuficiencia renal crónica, diálisis

\begin{abstract}
Chronic kidney disease (CKD) of non-traditional causes (CKDnT) has been described in a variety of geographic contexts. Two regions where it is well-documented are the Pacific coast of Central America and regions of Sri Lanka. While little is known about the natural history of this pathology, affected individuals are younger field workers, exposed to heat stroke, live under 200 masl and tend to have minimal proteinuria until late in the course of disease and no relation with CKD traditional risk factors like diabetes or hypertension. The etiology of the epidemic of CKDnT is unknown but there are well recognized risk factor like heath stroke, frequent dehydration. Rabdomiolysis, use of AINES in a context of poverty, low birth weight and malnutrition. The aim is to document the prevalence of patients on hemodialysis in southwestern Guatemala who have CKDnT. This cross-sectional descriptive study interviewed patients on hemodialysis units (Escuintla, Mazatenango and Retalhuleu) on their health and occupational history. Patients were classified according to whether they had diabetes, hypertension or obesity or neither. The proportion of patients with and without these traditional CKD risk factors was recorded and the association between demographic and occupational factors and a lack of traditional CKD risk factors analyzed using multivariate logistic regression. 171 (71\%) patients out of 242 had CKDnT risk factors. While agricultural work history was common, only travel time $>30 \mathrm{~min}$ and age $<50$ years old were significantly associated with CKD in the absence of traditional risk factors. The use of AINES drugs and sodas was common. The prevalence of CKDnT is higher in this sample of patients receiving hemodialysis in Southwestern Guatemala. The same phenomenon occurs in El Salvador and Nicaragua. So, we demonstrated that CKDnT happens also in Guatemalan population.
\end{abstract}

